\title{
COMPARATIVE ANALYSIS OF ANTHROPOMETRIC DIMENSIONS OF MALE AND FEMALE AGRICULTURAL WORKERS IN SOUTH-EASTERN NIGERIA
}

\author{
0. Oduma ${ }^{1, *}$ and S. I. Oluka ${ }^{2}$

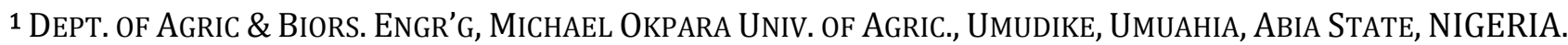

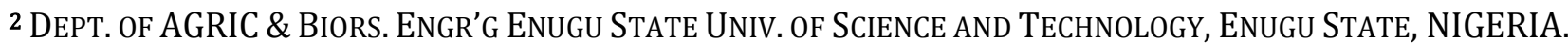 \\ Email addresses: ${ }^{1}$ odumaoke@gmail.com, ${ }^{2}$ ikeoluka@yahoo.com
}

\begin{abstract}
A comparative analysis of the anthropometric body dimensions of the male and female agricultural workers was conducted in South-Eastern Nigeria to ascertain the variations that exist among the body characteristics/dimensions of the male and female agricultural workers in the area. Thirty (30) anthropometric dimensions considered useful in the design of the agricultural equipment alongside with the heart rate of the workers were studied. Male and female agricultural workers within the age limit of 20-60 years were used for the study. Results obtained revealed that male agricultural workers had greater body dimensions than the females except in the waist circumferences and hip breadths in which the male measured average of $81.1 \mathrm{~cm}$ and $34.4 \mathrm{~cm}$ respectively and the female recorded $88.7 \mathrm{~cm}$ and $42.1 \mathrm{~cm}$ at waist and hip regions respectively. The comparison further showed that male agricultural workers had average stature and body weight of $168.3 \mathrm{~cm}$ and $65.9 \mathrm{~kg}$ respectively with the $5^{\text {th }}$ and $95^{\text {th }}$ percentiles of $162.75 \mathrm{~cm}$ and $175.77 \mathrm{~cm}$ respectively in stature; and $60.15 \mathrm{~kg}$ and $71.73 \mathrm{~kg}$ in body weight respectively. While the female recorded mean stature and body weight of $163.2 \mathrm{~cm}$ and $64.8 \mathrm{~kg}$ respectively with the corresponding $5^{\text {th }}$ and $95^{\text {th }}$ percentiles of $153.96 \mathrm{~cm}$ and $172.17 \mathrm{~cm}$ respectively in stature and $60.04 \mathrm{~kg}$ and $69.35 \mathrm{~kg}$ respectively in body weight. The males had average heart (pulse) rate of 73.8 beats/min while the females had 70.5 beats/min. The comparison generally did not show much variations, which implies that implements/machine designed for the male workers could suit the female workers or might be adjusted to suit the female workers.
\end{abstract}

Key words: Anthropometry, agricultural workers, comparison, machine design, south-east Nigeria.

\section{INTRODUCTION}

Anthropometry involves the systematic measurement of the physical properties of the human body size and shape [1]. According to [2], anthropometric body dimensions play significant roles in human-machine interaction, industrial design, clothing design, ergonomics and architecture where statistical data about the distribution of body dimensions in the population are used to optimize products. It varies considerably across gender, race and age; and within a particular group, the anthropometry differs due to nutritional status and nature of work; and to achieve better performance and efficiency along with higher comfort and safety to the operators it is imperative to design tools, equipment and workplaces keeping in view of the anthropometric data of the agricultural workers. Yadav, et al [3] also noted that the present need for the use of agricultural mechanization require a good knowledge and proper design of agricultural equipment with special consideration to efficiency, safety, and comfort of people using them. It is in this opinion that [4] maintained that ergonomics is the science of fitting work to the users; instead of forcing the users to fit the work and that a good match can be obtained if anthropometric data is used.

Onuoha, et al [5] explained ergonomics as the application of measurements to products in order to improve their human use. They maintained that it often involves research into the way people interact with products and environment around them and that anthropometric data is used to determine the size, shape, and/or form of a product, making it more comfortable for human use. The overall working efficiency of human-machine environment and resultant discomfort has severe impact while using tools and machinery in different work conditions. Anthropometric data have wide range of applications in the design of agricultural machinery among other physical equipment and facilities. It is needed in the design of products as it varies between individuals and nations [6]. Anthropometric body dimensions play significant role in human-machine interaction. The overall human efficiency of human-

\footnotetext{
* Corresponding author, tel: +234-803-884-5074
} 
machine environment and resultant discomfort have severe impact while using farm equipment and/or machinery, and the anthropometric dimensions developed from one region may not be appropriate to be used when designing machines or tools for people in other ethnic origin

Despite the various approaches to modern technology on agricultural machinery/equipment design, human drudgery in farm operations have not been fully arrested in Nigeria especially in the South-eastern part of Nigeria. In western countries, large amount of anthropometric data are available for reference. The anthropometric data bank assembled and maintained by the Aerospace Medical Research Laboratories, Dayton, Ohio, is the largest and most comprehensive data in the world [7]. However [5] noted that it does not contain any data on the Nigeria population. The anthropometric data of Nigeria agricultural workers are not by any means considered in the design of agricultural equipment and yet most of the equipment being used are imported from western countries.

Some agricultural machines create discomfort and at times breakdown quickly due to various discrepancies in ergonomic principles with respect to Nigeria agricultural workers using them. Yadav, et al [8] in another report identified various factors such as gender, age, race, nutritional status, body dimensions, and nature of work among others which vary widely across every region, state and country. This therefore implies that there must be considerable difference between the male and female anthropometric dimensions in Nigeria just like in the western countries. Most of the farm operations are shared by both genders (male and female). In Nigeria, farm operations such as ploughing, harrowing, leveling, pudding are exclusively done by male agricultural workers while uprooting of seedlings, weeding, transplanting are done by female. However some operations such as seed planting, application of weed/pest controls, fertilizer application, transportation etc. are done by both genders [5]. Based on this premise, anthropometric body dimensions of both genders should be explored, compared and considered in designing any machinery or tool meant to perform a specific agricultural operation. This will therefore boost the production and enhance the safety and comfort of the operators of the machines.

One of the important factors considered in the design and fabrication of agricultural equipment/ machinery is the anthropometric dimensions of the operators which vary with age, race, gender, nature of work/work space, and nutritional status among other things across various regions. In western countries, large amount of anthropometric data are available for reference in the design of agricultural machines, but in Nigeria, the anthropometric dimensions of the agricultural workers are not available and therefore not being considered in the design of the equipment and yet most of the equipment are imported from western countries resulting to low productivity, discomfort and unsafe operation of the machines.

Furthermore, most of the farm operations in the southeastern region of Nigeria are handled by male and female agricultural workers, unfortunately, there is no available anthropometric data in this region to enable the designers of agricultural equipment design the machine to suit them. Knowledge of the anthropometric data of the male and female agricultural workers and their relative differences will assist the engineers to comparatively design agricultural machines that will suit them and enhance their comfort, safety and efficiency of operation. The main aim of this research work is to develop an anthropometric database for male and female agricultural workers in the rural areas of south-eastern region of Nigeria for a better design of farm machinery to suit them for safety, comfort and efficient operation. The specific objectives are: to compare the male and female anthropometric dimensions in the rural areas of southeastern region of Nigeria; to determine the percentage difference in mean anthropometric dimensions for male and female agricultural workers in south-eastern region of Nigeria and to compare the anthropometric dimensions with other ethnic populations of the world.

\section{MATERIALS AND METHOD}

\subsection{Samples for the Study}

The samples for the study consist of 600 agricultural workers (300 each of male and female) within the age limit of 20-60 years selected randomly from the five states that made up the South- Eastern region of Nigeria, namely: Abia, Anambra, Ebonyi, Enugu and Imo State.

\subsection{Apparatus Used}

The following anthropometric equipment was used for the study:

- An anthropometer was used in measuring various body dimensions at standing and sitting postures.

- Weighing balance of $1 \mathrm{~kg}$ sensitivity and $150 \mathrm{~kg}$ capacity was used for measuring the body weight of the subjects.

- Measuring tape was used for measuring lengths and widths of some body parts.

- Vernier caliper was used for measuring the internal and external grip diameters.

- Grip strength dynamometer was used for measuring grip strength.

- Statoscope was used for measuring rate of heart beat. 
2.3 Anthropometric Measurement Procedure / Data Collection

Thirty (30) anthropometric body dimensions considered useful for design of agricultural equipment/machines were measured alongside with the heart rates. The standard anthropometric definitions of measurements and techniques used by [4] and [9] as applied by [5] were adopted in the study.

Table 1: comparison of mean anthropometric dimensions of male and female agricultural workers in south-east Nigeria

\begin{tabular}{|c|c|c|c|c|c|c|c|c|c|c|c|c|c|c|}
\hline \multirow{2}{*}{$\begin{array}{l}\text { Body } \\
\text { Dimension }\end{array}$} & \multicolumn{6}{|c|}{ MALE (mean values) } & \multicolumn{6}{|c|}{ FEMALE (mean values) } & \multirow{2}{*}{$\begin{array}{l}\text { Mean } \\
\text { diff. }\end{array}$} & \multirow{2}{*}{$\begin{array}{c}\text { Percentage } \\
\text { difference } \\
(\%)\end{array}$} \\
\hline & Abia & Anambra & Ebonyi & Enugu & Imo & $\begin{array}{l}\text { Overall } \\
\text { mean }\end{array}$ & Abia & Anambra & Ebonyi & Enugu & Imo & $\begin{array}{l}\text { Overall } \\
\text { mean }\end{array}$ & & \\
\hline Stature & 168.75 & 168.75 & 171.8 & 171.2 & 170.1 & 168.3 & 162.75 & 163.95 & 165.8 & 167.9 & 155.5 & 163.2 & 5.1 & 3.03 \\
\hline Weight, Kg & 65.40 & 66.65 & 69.60 & 70.8 & 57.1 & 65.9 & 57.2 & 64.0 & 67.1 & 76.2 & 59.4 & 64.8 & 1.1 & 1.7 \\
\hline $\begin{array}{l}\text { Standing Eye } \\
\text { Height }\end{array}$ & 161.05 & 160.30 & 163.3 & 164.5 & 154.1 & 160.60 & 150.55 & 155.2 & 155.1 & 160.5 & 154.8 & 155.2 & 5.4 & 3.4 \\
\hline $\begin{array}{l}\text { Shoulder } \\
\text { Breadth }\end{array}$ & 49.10 & 47.30 & 51.5 & 52.2 & 54.0 & 50.8 & 38.9 & 31.6 & 48.8 & 54.6 & 57.5 & 46.3 & 4.50 & 8.90 \\
\hline $\begin{array}{l}\text { Shoulder } \\
\text { Height }\end{array}$ & 143.75 & 42.30 & 147.40 & 152.0 & 148.7 & 146.8 & 138.6 & 137.1 & 142.3 & 141.5 & 135.7 & 141.3 & 5.5 & 3.7 \\
\hline $\begin{array}{l}\text { Shoulder } \\
\text { Elbow Length }\end{array}$ & 38.25 & 39.15 & 34.2 & 39.3 & 39.8 & 38.10 & 36.45 & 36.65 & 31.80 & 37.4 & 39.10 & 36.3 & 1.8 & 4.70 \\
\hline Hand Length & 19.55 & 21.25 & 19.70 & 20.6 & 19.6 & 20.10 & 18.15 & 19.8 & 18.30 & 18.90 & 19.0 & 18.80 & 1.30 & 6.5 \\
\hline Hand Breadth & 8.65 & $8 . .25$ & 8.7 & 9.0 & 8.0 & 8.50 & 7.20 & 7.35 & 6.80 & 7.60 & 7.30 & 7.20 & 1.30 & 15.30 \\
\hline Elbow Height & 104.25 & 105.25 & 106.10 & 106.7 & 95.10 & 103.3 & 100.4 & 102.2 & 102.6 & 97.3 & 92.80 & 99.10 & 4.20 & 4.10 \\
\hline $\begin{array}{l}\text { Elbow Rest } \\
\text { Height }\end{array}$ & 24.95 & 25.05 & 26.10 & 26.30 & 20.6 & 24.60 & 22.25 & 22.50 & 23.70 & 24.40 & 19.40 & 22.40 & 2.2 & 8.90 \\
\hline $\begin{array}{l}\text { Grip } \\
\text { Strength, Kg }\end{array}$ & 41.6 & 42.90 & 52.30 & 49.20 & 47.60 & 46.70 & 40.25 & 43.50 & 46.30 & 42.0 & 43.50 & 43.10 & 3.60 & 7.70 \\
\hline Grip Diameter & 4.70 & 5.10 & 5.70 & 6.0 & 5.0 & 5.30 & 4.00 & 5.05 & 4.80 & 5.40 & 4.70 & 4.80 & 0.50 & 9.40 \\
\hline 11. External & 7.35 & 7.95 & 8.20 & 8.60 & 7.90 & 8.00 & 6.30 & 7.95 & 7.0 & 7.30 & 7.80 & 7.30 & 0.70 & 8.80 \\
\hline $\begin{array}{l}\text { Hand } \\
\text { Circumference }\end{array}$ & 20.9 & 21.70 & 20.50 & 21.60 & 21.60 & 21.30 & 19.35 & 19.30 & 18.20 & 19.10 & 21.20 & 19.40 & 1.90 & 8.90 \\
\hline $\begin{array}{l}\text { Forearm Hand } \\
\text { Length }\end{array}$ & 49.90 & 49.90 & 51.10 & 52.30 & 48.70 & 50.4 & 48.4 & 48.85 & 47.8 & 49.1 & 45.8 & 48.0 & 2.4 & 4.5 \\
\hline $\begin{array}{l}\text { Forward Grip } \\
\text { Reach }\end{array}$ & 75.20 & 75.90 & 71.80 & 76.40 & 73.70 & 74.60 & 75.15 & 71.18 & 68.70 & 68.20 & 71.10 & 70.8 & 3.8 & 5.1 \\
\hline $\begin{array}{l}\text { Waist } \\
\text { Circumference }\end{array}$ & 80.75 & 77.50 & 81.3 & 81.15 & 84.9 & 81.1 & 87.45 & 83.70 & 85.4 & 91.7 & 97.5 & 88.7 & -7.6 & -9.6 \\
\hline Sitting Height & 81.75 & 82.45 & 81.3 & 81.9 & 74.8 & 80.4 & 73.75 & 71.33 & 74.2 & 68.3 & 69.7 & 71.5 & 8.9 & 11.1 \\
\hline $\begin{array}{l}\text { Sitting Eye } \\
\text { Height } \\
\text { Sitting }\end{array}$ & 68.50 & 69.20 & 69.4 & 74.3 & 60.7 & 68.4 & 65.4 & 65.80 & 64.9 & 63.4 & 50.8 & 62.0 & 6.4 & 9.4 \\
\hline $\begin{array}{l}\text { Shoulder } \\
\text { Height }\end{array}$ & 54.00 & 56.0 & 54.5 & 74.3 & 49.7 & 54.20 & 50.10 & 55.40 & 50.80 & 51.30 & 42.30 & 50.0 & 4.20 & 7.70 \\
\hline Hip Breadth & 33.00 & 31.75 & 34.0 & 37.10 & 36.20 & 34.40 & 29.80 & 31.10 & 39.40 & 67.0 & 43.40 & 42.10 & -7.70 & -22.10 \\
\hline Knee Height & 55.80 & 56.60 & 57.20 & 49.80 & 51.20 & 54.10 & 52.10 & 54.60 & 53.0 & 44.60 & 45.60 & 50.0 & 4.10 & 7.6 \\
\hline $\begin{array}{l}\text { Popliteal } \\
\text { Height }\end{array}$ & 49.70 & 49.55 & 50.50 & 50.6 & 46.30 & 49.30 & 46.45 & 46.25 & 48.10 & 43.00 & 44.30 & 46.60 & 2.70 & 5.50 \\
\hline $\begin{array}{l}\text { Knuckle } \\
\text { Height }\end{array}$ & 65.00 & 67.25 & 67.30 & 65.60 & 58.40 & 64.80 & 61.65 & 65.65 & 64.30 & 59.70 & 49.30 & 60.20 & 4.60 & 7.10 \\
\hline $\begin{array}{l}\text { Buttock Knee } \\
\text { Leight } \\
\text { Buttock }\end{array}$ & 57.05 & 58.35 & 50.60 & 56.40 & 54.50 & 55.40 & 53.95 & 57.10 & 46.40 & 50.70 & 47.30 & 51.10 & 4.3 & 7.80 \\
\hline $\begin{array}{l}\text { Popliteal } \\
\text { Length }\end{array}$ & 48.65 & 49.35 & 50.80 & 50.70 & 49.60 & 49.80 & 45.30 & 46.85 & 46.20 & 45.70 & 34.60 & 44.90 & 4.90 & 9.80 \\
\hline $\begin{array}{l}\text { Functional } \\
\text { Leg Length }\end{array}$ & 95.25 & 95.85 & 96.30 & 97.40 & 94.30 & 95.60 & 91.70 & 91.05 & 91.60 & 91.0 & 87.0 & 90.5 & 5.10 & 5.3 \\
\hline Foot Length & 32.55 & 32.40 & 32.6 & 33.20 & 29.40 & 32.0 & 29.5 & 29.95 & 29.90 & 14.50 & 24.80 & 25.70 & 6.30 & 19.70 \\
\hline $\begin{array}{l}\text { Thigh } \\
\text { Clearance }\end{array}$ & 14.35 & 14.45 & 14.60 & 15.80 & 12.30 & 14.30 & 11.25 & 12.15 & 12.10 & 13.10 & 11.50 & 12.0 & 2.0 & 16.10 \\
\hline $\begin{array}{l}\text { Metacarpal } \\
\text { Height }\end{array}$ & 66.05 & 66.75 & 66.0 & 69.6 & 59.90 & 65.70 & 84.45 & 64.25 & 60.7 & 62.0 & 55.0 & 65.30 & 0.40 & 0.60 \\
\hline
\end{tabular}


Prior to the collection of the data, some persons (male and female) were trained on how to take measurements of body dimensions. The process for data collection was properly explained to the trained personnel so as to maintain accuracy in their measurements and to seek full cooperation from the subjects. In the process, the subjects were asked to stand on the platform of the anthropometer with their feet well closed, their bodies vertically erect, while heels, buttocks and shoulders touch the vertical plane; the arm of the anthropometer was adjusted according to the subject's height and measurement was recorded from the vertical scale. Measurements were also taken in sitting postures. In this case subjects were asked to sit with their body vertically erect, while their shoulders and head touch the vertical plane and their feet completely touch the base platform. In all the measurements with anthropometer, the subjects were bare footed. The vernier caliper was used to measure the internal and external grip diameter while the grip strength dynamometer was used to measure the grip strength of the subjects. The measuring tape was used to measure waist breadth, waist circumference, foot length, and hand breadth across thump, hand height at metacarpal etc. The weighing balance was used for body weight measurement; the statoscope was used for measuring rate of heart beat. For every subject, measurements of a given body dimension was repeated for three times and average value of the dimension was taken as the real dimension; this is to avoid error in the measurements.

\subsection{Data Analysis}

The data collected from the measurement was analyzed using range, mean, standard deviation, percentile values $\left(5^{\text {th }}, 50^{\text {th }}\right.$ and $95^{\text {th }}$ percentile $)$ and percentages. The percentile was used to adjudge the proportion of a group of individuals who exceed or fall below some possible design limit; therefore, apart from the mean; the $5^{\text {th }}$ and $95^{\text {th }}$ percentile values of body dimensions were calculated to decide various possible design limits of farm machinery and work place layout to be operated by male or female workers [10]. The percentage was used to determine the percentage difference or variation in the set of data obtained for male and female agricultural workers. The percentile was calculated from the formula suggested by [11]

$$
X=\mu+Z Q
$$

In (1), $X$ is the Percentile; $\mu$ is the mean values; $Q$ is the standard deviation; $\mathrm{Z}=$ constant $=-1.645$ for $5^{\text {th }}$ percentile; 0 for $50^{\text {th }}$ and 1.645 for $95^{\text {th }}$ percentile

The standard deviation was computed using the expression:

$$
\mathrm{S}=\sqrt{\frac{\Sigma f(X-X)^{2}}{N}}
$$

In (2), $\mathrm{S}$ is the standard deviation; $\Sigma$ is the summation; $\mathrm{f}$ is the frequency; $\mathrm{x}$ is the measures of body dimensions $\mathrm{x}$ mean values of body dimension (given as $\frac{\Sigma f X}{N}$ ); $\mathrm{N}$ is the number of subjects measured.

\section{RESULTS AND DISCUSSION \\ 3.1 Results}

The data collected from the study was analyzed using the range, mean, standard deviation, percentile values and percentages; and were presented in descriptive statistical tables. The mean, standard deviation and percentage values revealed the differences in anthropometric dimensions that exist between the male and female agricultural workers while the percentile values provide a basis for judging the proportion of a group of individuals who exceed or fall below some possible design limits. Therefore, the $5^{\text {th }}, 50^{\text {th }}$ (mean) and $95^{\text {th }}$ percentile values of the body dimensions were calculated to decide various possible design limits of farm machinery and workplace layout to be operated by male or female agricultural workers in the study area. Tables 1 and 2 show the results of the research work.

Table 2: Comparison of anthropometric dimensions of male and female agricultural workers of South-East Nigeria with other

\begin{tabular}{|c|c|c|c|c|c|c|c|c|c|c|}
\hline \multirow[b]{2}{*}{ Body Dimension } & \multicolumn{5}{|c|}{ MALE } & \multicolumn{5}{|c|}{ FEMALE } \\
\hline & $\begin{array}{l}\text { Present study } \\
\text { south-eastern } \\
\text { Nigeria }\end{array}$ & $\begin{array}{c}\text { Agrawal et al } \\
(2010) \\
\text { India }\end{array}$ & $\begin{array}{c}\text { Yokohori } \\
\text { (1982) } \\
\text { Japanese }\end{array}$ & $\begin{array}{c}\text { Haslagrave } \\
\text { (1980) } \\
\text { British }\end{array}$ & $\begin{array}{l}\text { Shao and } \\
\text { Zhou } \\
(1990) \\
\text { Chinese }\end{array}$ & $\begin{array}{l}\text { Present study } \\
\text { south-eastern } \\
\text { Nigeria }\end{array}$ & $\begin{array}{l}\text { Agrawal et al } \\
(2010) \\
\text { India }\end{array}$ & $\begin{array}{l}\text { Anonymous } \\
(1974) \\
\text { Japanese }\end{array}$ & $\begin{array}{c}\text { Haslagrave } \\
(1980) \\
\text { British }\end{array}$ & $\begin{array}{l}\text { Shao and } \\
\text { Zhou (1990) } \\
\text { Chinese }\end{array}$ \\
\hline Stature & 168.3 & 161.4 & 165.8 & 173.81 & 168.82 & 163.2 & 150.8 & 159.60 & 171.81 & 158.62 \\
\hline Weight, kg & 65.9 & 53.7 & NA & NA & NA & 64.8 & 47.0 & NA & NA & NA \\
\hline $\begin{array}{l}\text { standing eye } \\
\text { height }\end{array}$ & 160.6 & NA & NA & NA & NA & 155.5 & NA & 144.70 & NA & 148.03 \\
\hline shoulder breadth & 50.8 & NA & NA & NA & NA & 46.3 & NA & NA & NA & NA \\
\hline shoulder height & 146.8 & 132.7 & 134.5 & NA & 142.10 & 141.3 & 124.2 & 127.0 & NA & 132.03 \\
\hline
\end{tabular}
ethnic origins of the world 


\begin{tabular}{|c|c|c|c|c|c|c|c|c|c|c|}
\hline \multirow[b]{2}{*}{ Body Dimension } & \multicolumn{5}{|c|}{ MALE } & \multicolumn{5}{|c|}{ FEMALE } \\
\hline & $\begin{array}{c}\text { Present study } \\
\text { south-eastern } \\
\text { Nigeria }\end{array}$ & $\begin{array}{c}\text { Agrawal et al } \\
(2010) \\
\text { India }\end{array}$ & $\begin{array}{c}\text { Yokohori } \\
\text { (1982) } \\
\text { Japanese }\end{array}$ & $\begin{array}{c}\text { Haslagrave } \\
(1980) \\
\text { British }\end{array}$ & $\begin{array}{c}\text { Shao and } \\
\text { Zhou } \\
(1990) \\
\text { Chinese }\end{array}$ & $\begin{array}{l}\text { Present study } \\
\text { south-eastern } \\
\text { Nigeria }\end{array}$ & $\begin{array}{c}\text { Agrawal et al } \\
(2010) \\
\text { India }\end{array}$ & $\begin{array}{c}\text { Anonymous } \\
\text { (1974) } \\
\text { Japanese }\end{array}$ & $\begin{array}{c}\text { Haslagrave } \\
\text { (1980) } \\
\text { British }\end{array}$ & $\begin{array}{c}\text { Shao and } \\
\text { Zhou (1990) } \\
\text { Chinese }\end{array}$ \\
\hline $\begin{array}{l}\text { shoulder elbow } \\
\text { length }\end{array}$ & 38.1 & NA & NA & NA & NA & 36.3 & NA & NA & NA & NA \\
\hline hand length & 20.1 & 16.9 & NA & NA & NA & 18.8 & 16.1 & NA & NA & NA \\
\hline hand breadTH & 8.5 & 8.9 & NA & NA & NA & 7.2 & 8.6 & NA & NA & NA \\
\hline elbow height & 103.3 & 101.4 & NA & NA & NA & 99.1 & 96.0 & 98.30 & NA & NA \\
\hline elbow rest height & 24.6 & 24.6 & 24.0 & NA & NA & 22.4 & 22.7 & NA & NA & NA \\
\hline grip strength, kg & 46.7 & NA & NA & NA & NA & 43.1 & NA & NA & NA & NA \\
\hline $\begin{array}{l}\text { grip diameter } \\
\text { i. Internal } \\
\text { 11. external }\end{array}$ & $\begin{array}{l}5.5 \\
8.0\end{array}$ & $\begin{array}{l}4.0 \\
7.8\end{array}$ & $\begin{array}{l}\text { NA } \\
\text { NA }\end{array}$ & $\begin{array}{l}\text { NA } \\
\text { NA }\end{array}$ & $\begin{array}{l}\text { NA } \\
\text { NA }\end{array}$ & $\begin{array}{l}4.8 \\
7.3\end{array}$ & $\begin{array}{l}3.6 \\
6.3\end{array}$ & $\begin{array}{l}\text { NA } \\
\text { NA }\end{array}$ & $\begin{array}{l}\text { NA } \\
\text { NA }\end{array}$ & $\begin{array}{l}\text { NA } \\
\text { NA }\end{array}$ \\
\hline $\begin{array}{l}\text { hand } \\
\text { circumference }\end{array}$ & 21.3 & NA & NA & NA & NA & 19.4 & NA & NA & NA & NA \\
\hline $\begin{array}{l}\text { forearm hand } \\
\text { length }\end{array}$ & 50.4 & 40.9 & NA & 46.87 & NA & 48.0 & 39.5 & NA & NA & NA \\
\hline $\begin{array}{l}\text { forward grip } \\
\text { reach }\end{array}$ & 74.6 & NA & NA & NA & NA & 70.8 & NA & NA & 46.87 & NA \\
\hline $\begin{array}{l}\text { waist } \\
\text { circumference }\end{array}$ & 81.1 & 74.6 & NA & NA & NA & 88.7 & 72.4 & NA & NA & NA \\
\hline sitting height & 80.4 & 84.8 & 90.4 & 91.90 & 89.65 & 71.5 & 78.4 & 85.0 & NA & 84.85 \\
\hline $\begin{array}{l}\text { sitting eye } \\
\text { height }\end{array}$ & 68.4 & 58.8 & 78.5 & 80.27 & 79.40 & 62.0 & 53.40 & NA & 91.90 & NA \\
\hline $\begin{array}{l}\text { sitting shoulder } \\
\text { height }\end{array}$ & 54.2 & NA & NA & 62.11 & NA & 50.0 & NA & NA & 80.27 & NA \\
\hline hip breadth & 34.4 & 30.0 & NA & NA & NA & 42.1 & 30.5 & NA & NA & NA \\
\hline knee height & 54.1 & 45.8 & NA & NA & NA & 50.0 & 42.8 & NA & NA & NA \\
\hline popliteal height & 49.3 & 41.7 & 40.2 & NA & 40.13 & 46.6 & 39.7 & 36.20 & NA & 38.27 \\
\hline knuckle height & 64.8 & NA & NA & NA & NA & 60.2 & NA & NA & NA & NA \\
\hline $\begin{array}{l}\text { buttock knee } \\
\text { leight }\end{array}$ & 55.4 & 52.5 & NA & NA & NA & 51.1 & 51.3 & 53.10 & NA & 52.78 \\
\hline $\begin{array}{l}\text { buttock popliteal } \\
\text { length }\end{array}$ & 49.8 & 43.1 & NA & NA & NA & 44.9 & 42.3 & 43.3 & NA & 43.18 \\
\hline $\begin{array}{l}\text { functional leg } \\
\text { length }\end{array}$ & 95.6 & NA & NA & NA & NA & 90.5 & NA & NA & NA & NA \\
\hline foot length & 32.0 & 23.5 & NA & NA & NA & 25.7 & 22.2 & NA & NA & NA \\
\hline thigh clearance & 14.3 & NA & NA & NA & NA & 12.0 & NA & NA & NA & NA \\
\hline $\begin{array}{l}\text { Metacarpal } \\
\text { height }\end{array}$ & 65.7 & NA & NA & NA & NA & 65.3 & NA & NA & NA & NA \\
\hline
\end{tabular}

NA = not available

Table 3 Average heart (pulse) rate of male and female agricultural workers in south-eastern zone of Nigeria

\begin{tabular}{lcc}
\hline Study area & $\begin{array}{c}\text { Average male } \\
\text { heart rate } \\
\text { (beats/min) }\end{array}$ & $\begin{array}{c}\text { Average female heart } \\
\text { rate (beats/min) }\end{array}$ \\
\hline Abia state & 70 & 71 \\
Anambra state & 72 & 73 \\
Ebonyi state & 77 & 75 \\
Enugu state & 72 & 70 \\
Imo state & 78 & 76 \\
Overall mean & 74 & 73 \\
\hline
\end{tabular}

\subsection{Discussion}

Table 1 presents the comparison of the male and female agricultural workers in South-Eastern Nigeria. It is observable from the result that the stature of the male is greater than the female by $5.1 \mathrm{~cm}(3.03 \%$ of the male stature) and the body weight of the male is also greater than the female by $1.1 \mathrm{~cm}(1.7 \%$ of the male's body weight). Similarly other dimensions followed the same trend with different dimensional values and percentage differences except for waist circumference and hip breadth in which the females' dimensions were greater than the males by $7.6 \mathrm{~cm}$ (9.4\% of the male's mean waist circumference) and hip by $7.7 \mathrm{~cm}$ (22.4\% of male's average hip dimensions). In general the body dimensions of the male and female do not vary much, therefore, tools and equipment designed based on data collected can effectively be utilized by both male and female agricultural workers within the region which is in agreement with the study of [12].

Table 2 showed the comparison of anthropometric dimensions of male and female agricultural workers with other ethnic origins of the world. The comparison showed some variations in the body dimensions of south-eastern Nigeria and other nations. The variations 
in the body dimensions may lead to having uncomfortable postures adopted while working with implements and machinery resulting to low work output. The mean stature of the British male and female workers was found to be highest with values of $173.8 \mathrm{~cm}$ and $171 \mathrm{~cm}$ respectively followed by Chinese male workers with average stature of $168.82 \mathrm{~cm}$; this was also followed by South- Eastern Nigeria workers (male and female), Japanese male, Indian male, Japanese female and the least was Chinese female with average stature of $158.62 \mathrm{~cm}$. It was generally observed from the comparison that the body dimensions of the male agricultural workers are higher than the female workers. However the variations are not much across most ethnic nations; therefore, implements designed for the male workers can suit or be adjusted to suit the females within the same ethnic origins.

Table 3.3 shows the average heart (pulse) rate for male and female agricultural workers in south east Nigeria. The average heart rate of the male agricultural workers range from $70-78$ beats/min while that of females fall within the range of $70-76$ beats $/ \mathrm{min}$. The slight difference observed in which the male average heart rate is higher than the female may be attributed to the fact that men have high oxygen consumption rate during work than the female because they do more difficult works than the females.

\section{CONCLUSION:}

The body dimensions of the male agricultural workers are slightly greater than that of the female workers except in the waist circumferences and hip breadths. However, the variations were not much across the entire geographical region. Therefore agricultural implements / machines designed for male agricultural workers within the region can suit or be adjusted to suit the female agricultural workers since the female participation in various agricultural operations in South-Eastern Nigeria is relatively equal to the male; there is greater need to develop improved implement to suit the capabilities of both male and female agricultural workers.

\section{RECOMMENDATION}

The application of ergonomic approach in designing farm implements and machinery is not very much in practice in developing countries like Nigeria due to lack of anthropometric database. Study of anthropometric body dimensions of this kind should therefore be extended to other geographical regions of Nigeria to guide the engineers or designers of agricultural equipment in designing and manufacturing the equipment to suit the users and make them work in good postures and maximize their output.

\section{REFERENCES}

[1] Dewangan, K. N.,Prasanma, G.V, Suja, P. L and Choudhury, M. D. "Anthropometric dimensions of farm youth of the north eastern region of India". International Journal of Industrial Ergonomics, 35(11): 979-989. 2005.

[2] Agrawal, K. N, Singh, K. P, and Satapathy, K. K. "Anthropometric consideration for farm tools/machinery design for ribal workers of north eastern India". Agric Engineering Int. CIGR Journal..12(1):143-150.. 2010.

[3] Yadav, R. L. P, Gite, N. K, and Randhawa, J. "An anthropometric of India female Agricultural workers". Agricultural Mechanization in Asia, Africa and Latin America, 31(3); 56-60. 2000.

[4] Pheasant, S. Body space: Anthropometry, Ergonomics and Design. Taylor and Francis, London.1986.

[5] Onuoha, S. N. Idike F. I and Oduma, O. "Anthropometry of South-Eastern Nigeria Agriculture Workers". International Journal of Engineering and Technology.. Vol.2, No 6.Pp. 962-968. 2012.

[6] Onuoha, S. N. Okafor, M. C and Oduma, O. Anthropometry dimensions and protective wears for Foot and head. Acase study of selected poly technic students in the South zone of Nigeria. JAET.Vol.20, No. 2.Pp. 11-16. 2014.

[7] NASA. Anthropometric Source Book. Vol.11. National Aeronautics and Space Administration Washington. 1978.

[8] Yadav, R. Tewari,V. K and Prasad, N. Anthropometric data of India Farm Workers- a modul analysis", Applied Ergonomics.,28(1):69-71. 1996.

[9] Dixit, J. and Namgial, D. "Anthropometry of farm workers of Kashmir region of India for equipment design". Journal of Agricultural Engineering.. 49(2): 8-15. 2012.

[10] Dixit, J. and Namgial, D. Sharma, S., Loanan, S. K, Kumar, D. "Anthropometric survey of farm workers of ladakl region of india and its application in equipment design". Agric eng. Int; CIGR journal. 16(2):80-88. 2000.

[11] Yadav, R. "Some ergonomic investigations on tractor operator workplace design", Kharagpur, India.1995.

[12] Kothari C. R. Research Methodology. Methods and Techniques. Second Revised Edition. New Age International Publishers. New Delhi. Pp185-344. 2013.

[13] Yokohori, E. Anthropometry of JASDF Personnel and its application for human engineering. Aeromedical laboratory. Japanese Airself Defence force TAB, Tokyo, Japan. 1972.

[14] Haslegrave, C. M. "Anthropometric profile of British car driver". Ergonomics, 23(5): 437-467. 1980.

[15] Shao, W. and Y. Zhou. "Design principles of wheeled tractor driver seat static comfort". Ergonomics, 33(7): 959-965. 1990

[16] Anonymous. Japanese Body Size Data. Human Engineering for Quality Life, Japan (in Japanese). Research Institute of Human Engineering for Quality Life. 1994. 